\title{
SEMI-CONTINUOUS ANAEROBIC CO-DIGESTION OF COW MANURE AND BANANA WASTE: EFFECTS OF MIXTURE RATIO
}

\author{
JoUte, Y.$^{1 *}$ - El BARI, H. ${ }^{1}-$ BelhadJ, S. ${ }^{1}-$ KAROUACH, F. ${ }^{1}-$ Gradi, Y $.{ }^{1}-$ Stelte, W. ${ }^{2}-$ \\ BJERRE, A. B. ${ }^{2}$ \\ ${ }^{1}$ Biogas Team - Biotechnology Laboratory, Environment and Quality- Faculty of Sciences - Ibn \\ Tofail University, B.P:133, 14000-Kenitra, Morocco \\ (phone: +212-5-37-32-92-00; fax : +212-5-37-37-40) \\ ${ }^{2}$ Center for Biomass and Biorefinery, Division for Energy and Climate, Danish Technological \\ Institute, DK-2630 Taastrup, Denmark \\ *Corresponding author \\ e-mail: yassine.joute@gmail.com; phone: +212-6-72-80-38-59 \\ (Received $9^{\text {th }}$ Jul 2015; accepted $5^{\text {th }}$ Mar 2016)
}

\begin{abstract}
Anaerobic co-digestion of cow manure (CM) and banana waste (BW) was investigated. The experiments have been carried out and were tested for different mixture ratios of CM:BW in terms of volatile solids : 100:0, 80:20, 60:40, 50:50, 40:60, 20:80 and 0:100 with the aim to maximize methane yield and methane production from the anaerobic co-digestion of cow manure and banana waste. The results obtained show that a maximum methane yield of $229 \mathrm{~mL}$ STP $/ \mathrm{g}$ VS added was obtained at a (CM): (BW) ratio of was 40:60 with a biodegradability of $86 \%$ for an organic loading rate in the range of 1.49$3.57 \mathrm{~kg}$ waste mixture/ $\left(\mathrm{m}^{3} \mathrm{~d}\right)$. The $\mathrm{pH}$ and alkalinity for all experiments were controlled and kept within an optimum interval of 7.1-7.6 for $\mathrm{pH}$ and 2-4 $\mathrm{g} \mathrm{CaCO}_{3} / \mathrm{L}$ for alkalinity. It was shown that banana waste and cow manure could easily be degraded by anaerobic co-digestion under mesophilic conditions, resulting in methane yields sufficient for commercial production of methane.
\end{abstract}

Keywords: anaerobic co-digestion, mixture ratio, cow manure, banana waste, mesophilic

\section{Introduction}

Anaerobic digestion is a sustainable green technology that has been extensively adapted for the treatment of various types of biological waste materials. The main product of this process is biogas, a renewable energy, formed mainly of methane and carbon dioxide. Co-digestion is the simultaneous anaerobic digestion of two or more organic wastes in one digester, it is used to increase methane production from lowyielding or difficult to digest materials. It has been shown that it enhances the biogas production, especially when treating certain residues such as cattle manure (Marañón et al., 2012). In the agricultural sector, anaerobic digestion has been established as a valuable resource for the production of biogas as a renewable source of energy; hence animal manures have become a requested and important raw material (Mata-Alvarez et al., 2010; Mata-Alvarez et al., 2011). The methane potential of manure comes from the digestion of the organic components in the faeces and in the straw used as bedding material, which is mainly: carbohydrates, proteins and lipids (Moller et al., 2004).

Cow manure, which contains water, nutrient and minerals as well as important microbes, is an excellent substrate for the production of biogas when co-digested with other kinds of waste materials such as organic industrial waste, household waste and sewage sludge. As such, cow manure serves as an excellent "carrier" substrate during the mixed digestion of wastes and allows anaerobic digestion of concentrated industrial waste, which would be difficult to treat separately (Angelidaki and Ellegaard, 2003). Its 
high water content acts as solvent for dry waste materials, its high buffering capacity regulates the optimum $\mathrm{pH}$ level in the reactor, and its high concentration of nutrients, is required for the optimal growth of bacteria (Angelidaki and Ellegaard, 2003). However, due to its low contents of carbon sources; anaerobic digestion of manure is often associated with poor methane yields (Mata-Alvarez et al., 2010; Mata-Alvarez et al., 2011). Thus, Co-digestion of manure with other substrates has been applied as a costeffective alternative to improve the process efficiency, and consequently resulting in economically feasible methane yields of biogas plants (Astals et al., 2013; Frigon et al., 2012; Banks et al., 2011). The advantages of co-digesting of animal manure together with other kinds of waste materials have been reported in different research studies. In that way, Angelidaki and Ellegaard (2003) reported the increase in biogas yield due to co-digestion of cow manure together with waste materials in anaerobic digestion process.

Banana residues are among the best anaerobic digestion feedstosk, due to its high organic composition. In agricultural sector, banana is the world's fourth most produced food commodity, after rice, wheat and apple. Bananas are grown in more than hundred countries, mostly in the developing world where they represent an important staple food (Khan et al., 2009). The cultivation, harvesting and processing of banana generates huge amounts of waste, mainly from leaves, stems and peels and to some extent the degraded banana fruit itself (Khan et al., 2009). Indiscriminate disposal of these wastes exhibits an environmental hazard due to the release of foul gases such as hydrogen sulphate and ammonia during its decomposition. The disposed waste materials serve also as a potential hatchery for insects and pests (Khan et al., 2009). Fruit-processing wastes, especially banana waste is highly biodegradable because of their rich organic matter and high moisture content. It has been found earlier that biowaste residues with a moisture contents above $50 \%$ are more suitable for bio-conversion processes rather than thermalconversion processes (Bardiya et al., 1999). The banana waste is a concentrated source of putrid organic waste, ideal for anaerobic digestion to produce energy while fermentation products can serve as fertilizer with high nutritional value, as well as a valuable energy source in form of biogas (El-Mashad and Zhang, 2010).

The goals of the present research work are to study the effect of mixture ratio at volatile solids basis on a semi-continuous anaerobic co-digestion of cow manure with banana waste (whole fruit), as well as investigating the methane yield, organic loading rate which can be treated, and process stability during the digestion. Seven experiments at laboratory scale were carried out under mesophilic condition using continuously stirred tank reactors. This study can provide a profitable solution for increasing methane potential production by introducing banana waste as co-substrate with cow manure, especially for rural areas and developing countries in which there is a high production of these types of waste.

\section{Materials and methods}

\section{Experimental Setup}

The reactors used in the laboratory for anaerobic digestion were continuous stirredtank reactors (CSTR), with a volume of one litre (Figure 1). These reactors have four orifices, the first to insert the substrate, the second one for the ventilation of biogas, the third for inert gas injection (nitrogen) to maintain anaerobic conditions, and the last one to remove effluents. The content of the reactors was mechanically stirred and 
mesophilic conditions were maintained using thermostatic jacket containing water heated to $37^{\circ} \mathrm{C}$. All reactors were worked in semi-continuous mode. The volume of methane produced during the process was measured using 1.5-L Boyle-Mariotte reservoirs connected to each reactor. To remove the $\mathrm{CO}_{2}$ produced during the process, tightly closed bubblers containing a $\mathrm{NaOH}$ solution $(6 \mathrm{~N})$ were connected between the two elements. The volume of methane displaced an equal measurable volume of water from the reservoirs. This volume was corrected in order to remove the effect of water steam pressure and the measured methane was then expressed at standard temperature and pressure conditions (STP: $0^{\circ} \mathrm{C}$ and $1 \mathrm{~atm}$ ) (Belhadj et al., 2014).

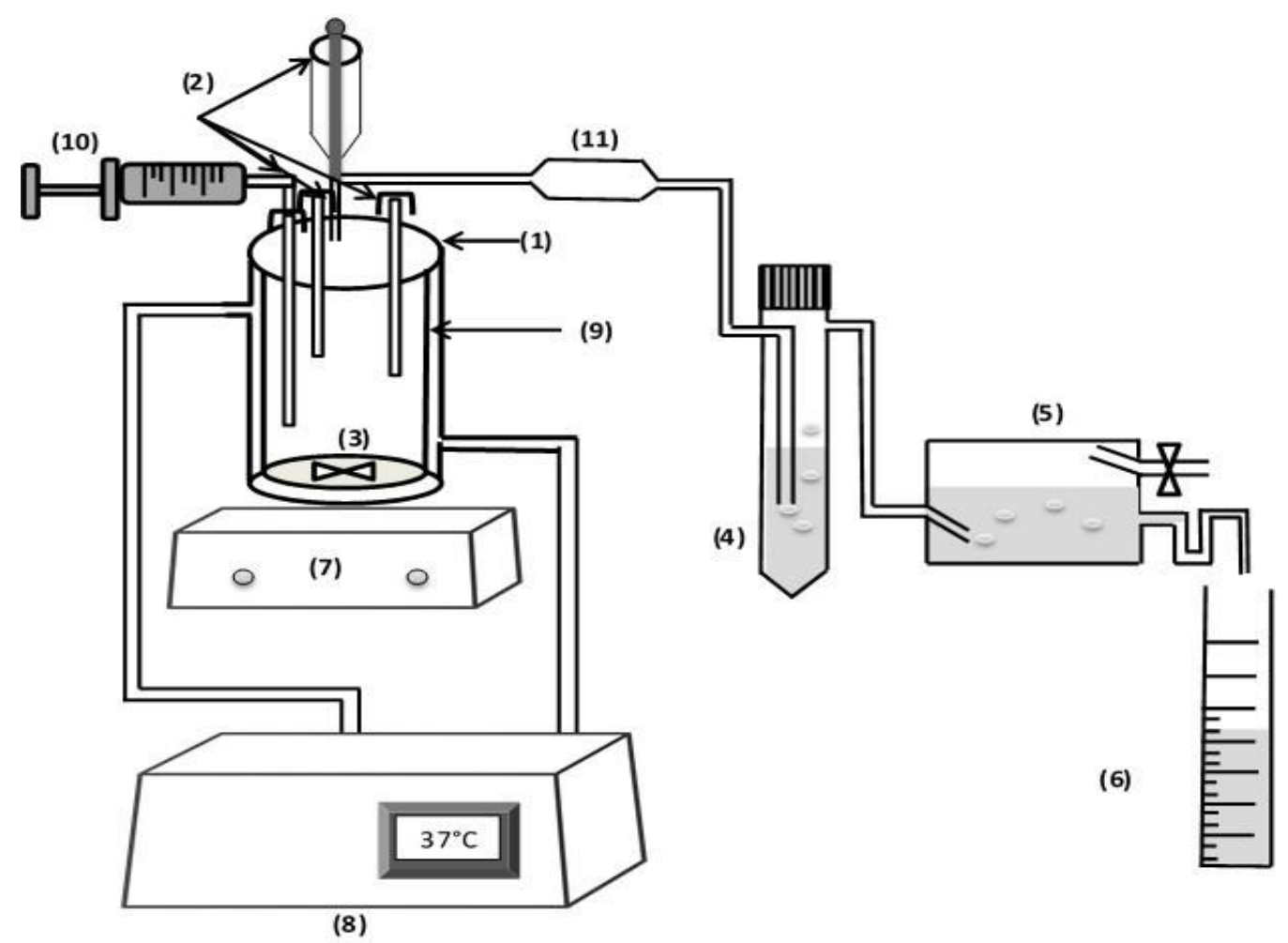

Figure 1. Schematic diagram of CSTR reactor system used. 1-CSTR digester; 2-Inlet/outlet sample; 3-Magnetic stir bar; 4-Tightly closed bubblers containing a NaOH solution (6 N); 5 Reservoir containing water; 6-Graduated cylinder; 7-Magnetic stirrer; 8-Thermostatic bath; 9Thermostatic jacket; 10-Syringe; 11-Biogas sampling tube.

Table 1. Experimental design

\begin{tabular}{l|l}
\hline Digesters & CM :BW (based on VS) \\
\hline R1 & $100: 0$ \\
\hline R2 & $80: 20$ \\
\hline R3 & $60: 40$ \\
\hline R4 & $50: 50$ \\
\hline R5 & $40: 60$ \\
\hline R6 & $20: 80$ \\
\hline R7 & $0: 100$ \\
\hline
\end{tabular}




\section{Substrate}

The substrates used for the anaerobic co-digestion were cow manure and banana waste. Cow manure was collected from Tiflet farm (West of Morocco) and stored in the laboratory at $4^{\circ} \mathrm{C}$ until usage. Banana waste was collected from a local supermarket. It was mixed, ground and subsequently frozen to $-4^{\circ} \mathrm{C}$ in plastic containers for subsequent storage. The main characterisation of both cow manure and banana waste are shown in Table 2.

Table 2. Substrates and mixtures ratios main characterization.

\begin{tabular}{c|c|c|c|c|c|c}
\hline \multicolumn{2}{c|}{} & $\mathbf{p H}$ & $\begin{array}{c}\text { Alkalinity } \\
(\mathbf{g ~ C a C O} / \mathbf{L})\end{array}$ & $\begin{array}{c}\text { Total Solids } \\
(\mathbf{g} / \mathbf{k g})\end{array}$ & $\begin{array}{c}\text { Volatile Solids } \\
(\mathbf{g} / \mathbf{k g})\end{array}$ & VS/TS(\%) \\
\hline \multirow{4}{*}{$\mathrm{CM}: \mathrm{BW}$} & $100: 0$ & $7.40 \pm 0.10$ & $1.80 \pm 0.05$ & $169 \pm 2.56$ & $142.12 \pm 1.45$ & $84 \pm 4$ \\
\cline { 2 - 7 } & $80: 20$ & $7.4 \pm 0,1$ & $3.10 \pm 0.50$ & $168.38 \pm 0.50$ & $140.30 \pm 1.87$ & $83 \pm 1$ \\
\cline { 2 - 7 } & $60: 40$ & $7.1 \pm 0,1$ & $2.60 \pm 0.15$ & $161.85 \pm 2.43$ & $136.5 \pm 1$ & $85 \pm 1$ \\
\cline { 2 - 7 } & $50: 50$ & $6.8 \pm 0,1$ & $2.10 \pm 0.3$ & $155.25 \pm 0.07$ & $134.75 \pm 0.6$ & $87 \pm 1$ \\
\cline { 2 - 7 } & $40: 60$ & $6.4 \pm 0,1$ & $1.40 \pm 0.25$ & $145.50 \pm 0.9$ & $135.6 \pm 1$ & $94 \pm 2$ \\
\cline { 2 - 7 } & $20: 80$ & $5.8 \pm 0,2$ & $0.65 \pm 0.01$ & $143.04 \pm 0.6$ & $131.1 \pm 1.18$ & $91 \pm 1$ \\
\cline { 2 - 7 } & $0: 100$ & $5 \pm 0.10$ & $0.90 \pm 0.01$ & $146.36 \pm 0.86$ & $136.57 \pm 1.31$ & $93 \pm 03$ \\
\hline
\end{tabular}

Result $=$ mean \pm standard deviation $(\mathrm{SD})$

ND: not determined

The reactors were initially loaded with $7 \mathrm{~g}$ VS/L of digested sludge from a municipal wastewater treatment plant (MWTP) as inoculum.

The $\mathrm{pH}$ value is a measure of the acidity or alkalinity of the liquid content of the reactor. Most methanogenic microorganisms have an optimum $\mathrm{pH}$ level for growth between 7 and 8, while the acid-forming bacteria often have a lower optimum $\mathrm{pH}$ level for optimal growth (Raposo et al., 2011; Angelidaki and Sandres, 2004). If the $\mathrm{pH}$ value of the waste to be tested is outside the optimal range, and if there is insufficient buffer capacity, the anaerobic process will be inhibited. During all experiments, the $\mathrm{pH}$ was controlled before and after each load.

\section{Experimental procedure}

In order to bio-stimulate the biomass prior to the experiments, reactors were first fed with a synthetic solution composed of glucose, sodium acetate and lactic acid. During this initial period, the organic load added to the reactors was gradually increased from 0.5 to $1.0 \mathrm{~g} \mathrm{VS} / \mathrm{L}$ over a 15 -day period. For acclimatization of the biomass resources, the reactors were fed with loads of $0.5 \mathrm{~g} \mathrm{VS} / \mathrm{L}$ in which the percentage of mixtures in the feeding process was increased from $25 \%$ to $100 \%$ after several loads. Subsequently, during each set of experiments with pure mixture, the organic load added to the reactors 
was gradually increased. In all cases three replicates of each load were fed to the digesters in order to ensure reproducibility and the volume of methane was measured as a function of time and samples were taken and analysed before and after feeding.

\section{Chemical analysis}

Analysis of the total solids (TS), the minerals solids, the volatile solids (VS), the $\mathrm{pH}$, and the bicarbonate alkalinity, were performed according to the Standard Methods for the examination of Water and Wastewater (APHA, 1989). For the determination of total solids, the samples were dried at $105^{\circ} \mathrm{C}$ for $24 \mathrm{~h}$, and total solid contents were calculated from the differences between weights before and after drying. The dried matters were heated at $550^{\circ} \mathrm{C}$ for $2 \mathrm{~h}$, and organic matter contents were calculated from the losses on ignition. Alkalinity was determined by a titration method at $\mathrm{pH} 4.5$.

\section{Results and discussion}

\section{Stability parameters of the process}

\section{The $\mathrm{pH}$ evolution}

Figure 2 shows the evolution of $\mathrm{pH}$ value during the period of anaerobic digestion, the $\mathrm{pH}$ value remained stable throughout the digestion process and there was no need to add alkalinity to the digester. To avoid an underestimation of the methane potential, most anaerobic digsetion experiments are carried out at $\mathrm{pH}$ values ranging from 7.0 to 7.8. If the $\mathrm{pH}$ value needs to be adjusted, diluted solutions of $\mathrm{NaOH}$, lime, or an acid solution such as $\mathrm{HCl}$, could be used (Li et al., 2011). In our experiments we usually use the normality of $0.1 \mathrm{~mol} / \mathrm{L}$ for both solutions.

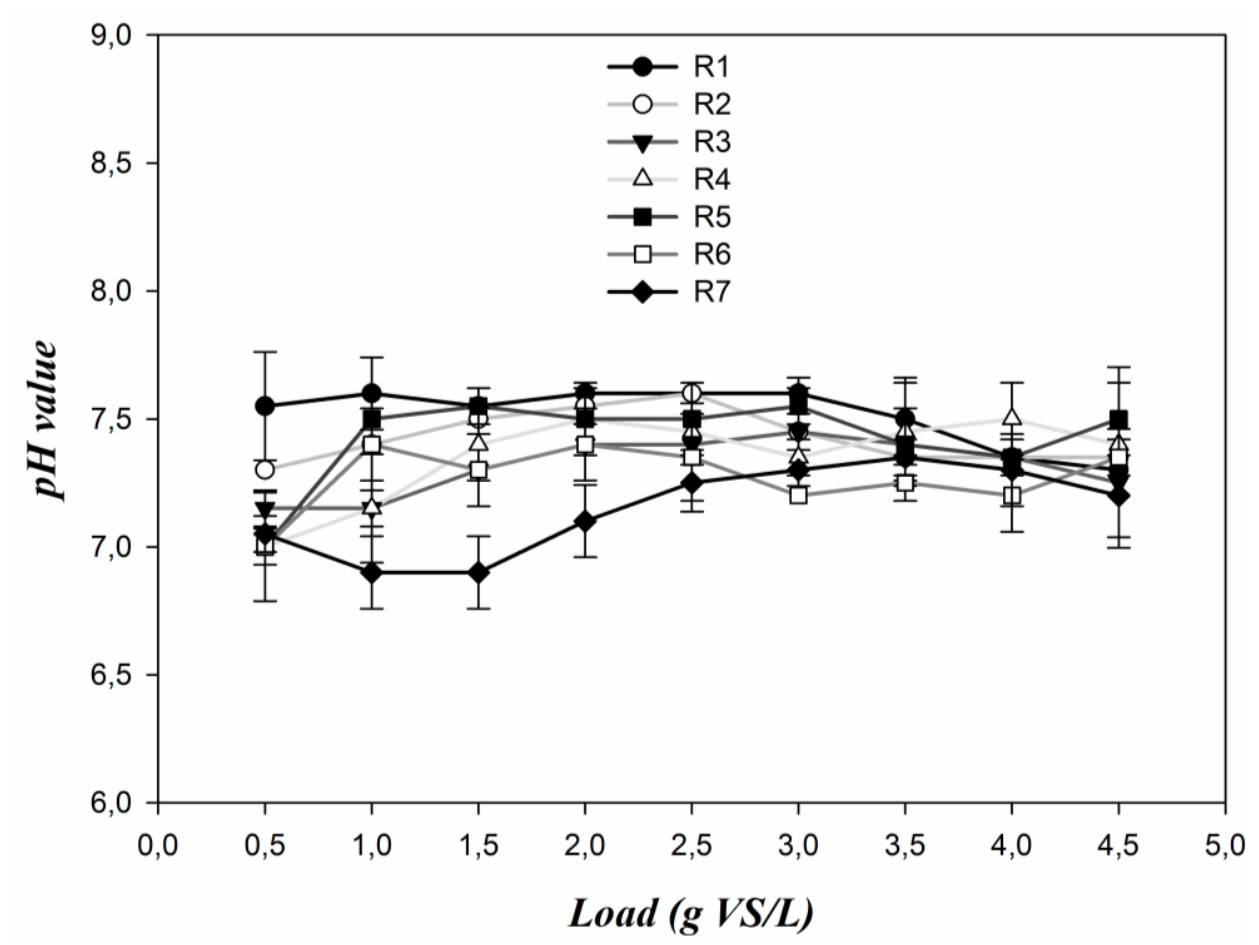

Figure 1. pH evolution in the substrate treatment phase of all anaerobic co-digestion experiments. 


\section{Alkalinity assessment}

All experiments have shown an acceptable and stable range between 2 and $4 \mathrm{~g}$ $\mathrm{CaCO}_{3} / \mathrm{L}$ of alkalinity during the process. The evolution of alkalinity throughout the different experiments is shown in Figure 3. (Nizami et al., 2009) reported that a concentration of $2-5 \mathrm{~g} \mathrm{CaCO}_{3} / \mathrm{L}$ provides a sufficiently high buffering capacity allowing a large increase in volatile fatty acids (VFA) at a minimum decrease of the $\mathrm{pH}$ value. It is also known as buffering capacity, due to the presence of various compounds mainly bicarbonate, carbonate and hydroxides. (Raposo et al., 2011).

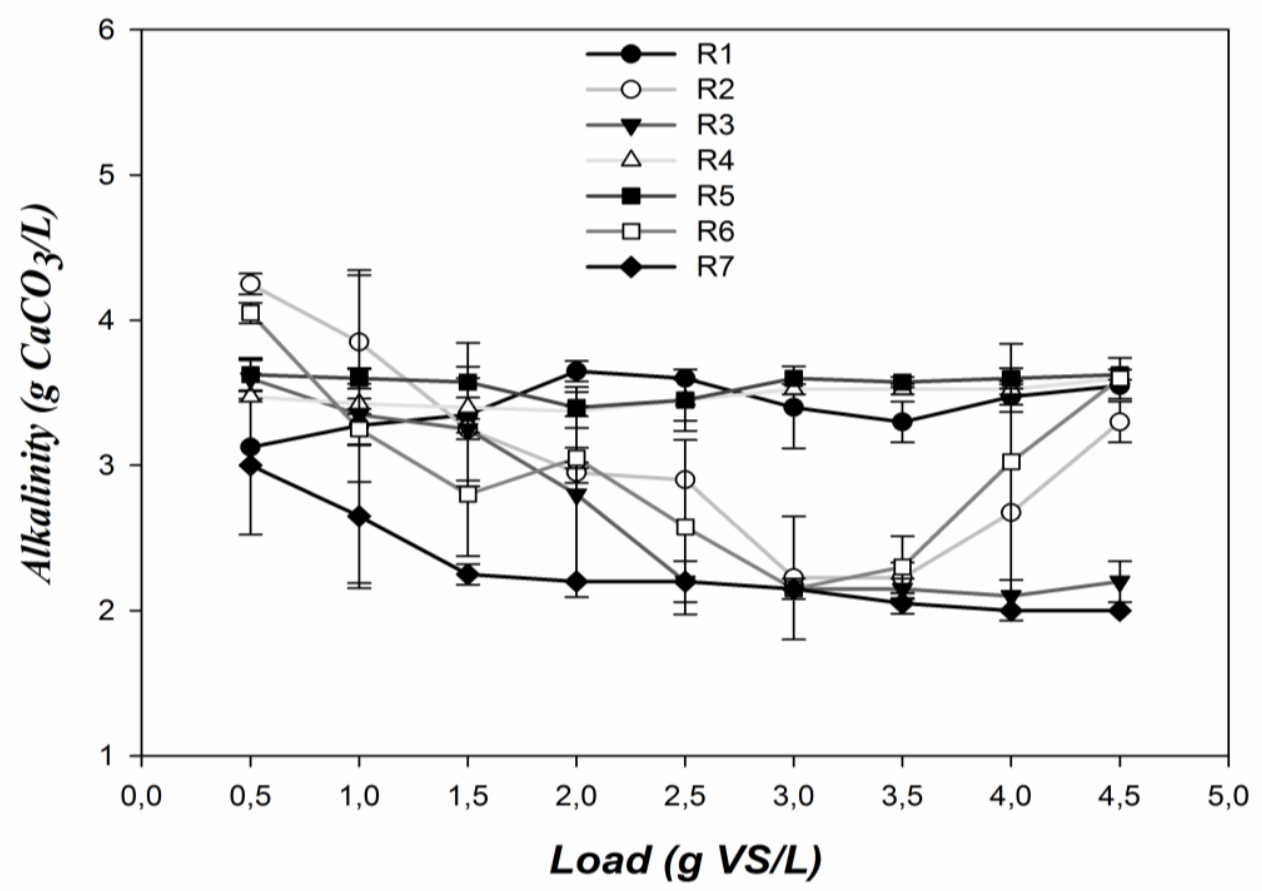

Figure 2. Alkalinity evolution in the substrate treatment phase of all anaerobic co-digestion experiments.

\section{Biodegradability and methane yield}

As shown in the Figure 4, the anaerobic digestion of cow manure gave a low biodegradability (50\%), and the increasing of the ratio of banana waste in the mixture improved the treatment efficacy, while the biodegradability of banana waste used as single substrate in anaerobic digestion was high (94\%).

The low biodegradability obtained by anaerobic digestion of cow manure can be justified by the fact that VS in cow manure is not highly degradable compared to that of other animal manures due to the high digestion efficiency of the rumen system in cows, along with their fibrous diet (Ann-Wilkie, 2005).

In addition, it can be observed from Table 3 that the content of lignin of $\mathrm{CM}$ is high 24.4 (\% TS) compared with that of BW (8.30\%TS), and as known, the content of lignin of a substrate affects negatively the biodegradability. In that way, the banana biowaste input contributes mainly to increase considerably the biodegradability to $94 \%$ (Figure 4 ), which is the positive result of co-digestion also seen in other studies. 


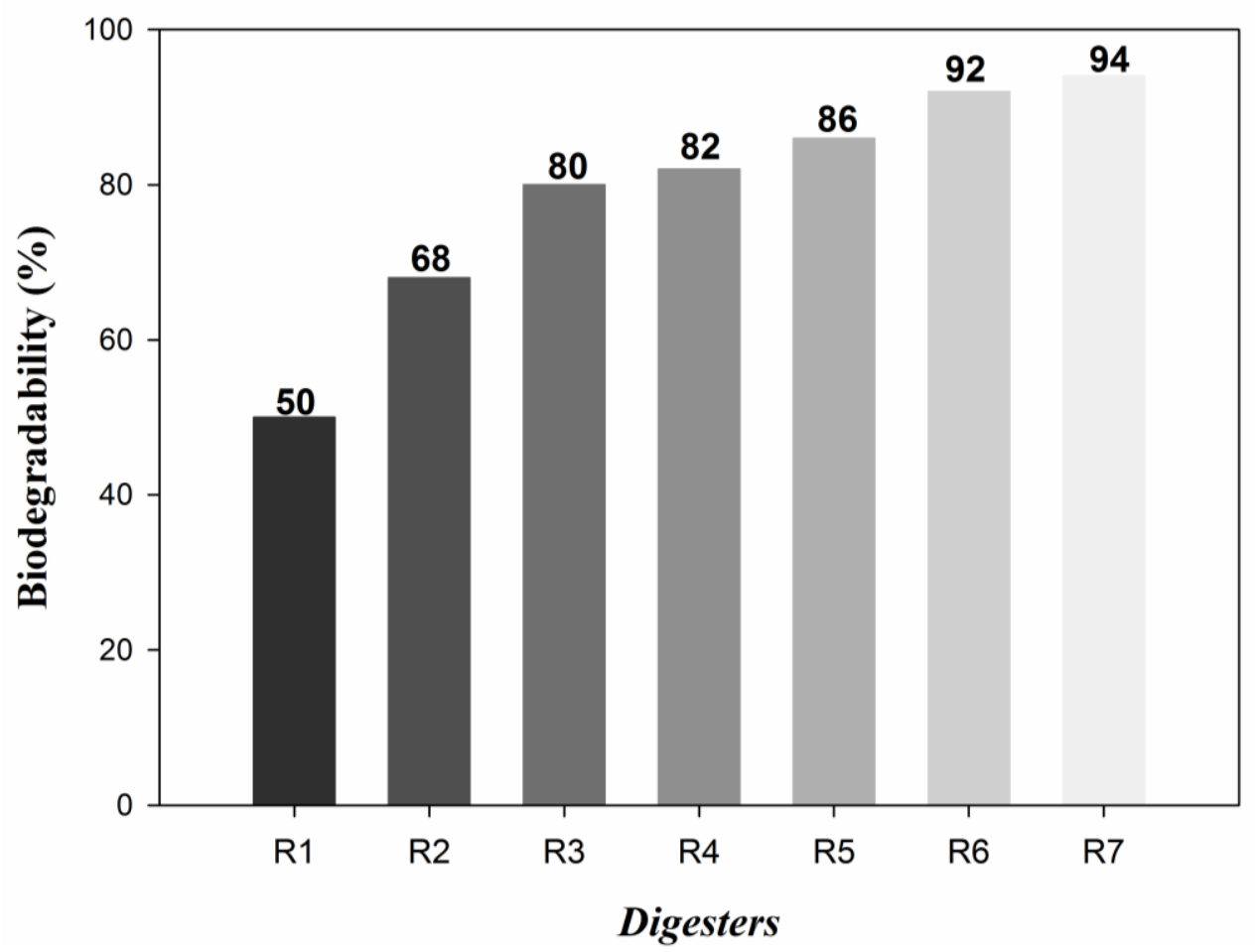

Figure 3. Biodegradability of all anaerobic co-digestion experiments.

Table 3. The full set of characterisation data of cow manure and banana waste (Gustavsson et al., 2014).

\begin{tabular}{c|c|c|c|c|c|c}
\hline $\begin{array}{c}\text { Nutrient and } \\
\text { sugar rich } \\
\text { feedstock }\end{array}$ & $\begin{array}{c}\text { Total } \\
\text { Solids }^{\mathbf{a}}\end{array}$ & $\begin{array}{c}\text { Ash } \\
\text { content } \\
(\% \mathbf{T S})\end{array}$ & $\begin{array}{c}\text { Glucan } \\
(\% \mathbf{T S})\end{array}$ & $\begin{array}{c}\text { Xylan } \\
(\% \mathbf{T S})\end{array}$ & $\begin{array}{c}\text { Arabinan } \\
(\% \mathbf{T S})\end{array}$ & $\begin{array}{c}\text { Klason } \\
\text { Lignin } \\
(\% \text { TS })\end{array}$ \\
\hline Cow manure $^{\mathrm{b}}$ & 93.88 & 20.02 & 27.61 & 18.06 & 2.51 & 24.14 \\
\hline Banana waste $^{\mathrm{c}}$ & 95.40 & 6.19 & 77.50 & 3.00 & 3.00 & 8.30 \\
\hline
\end{tabular}

${ }^{a}$ This is the dry matter of the dried and milled sample.

${ }^{\mathrm{b}}$ Nutrient rich feedstock

csugarrich feedstock

For methane yield, as shown in Figure 5, by fitting pairs of values of the maximum experimental volume of methane produced in each load $\left(\mathrm{mL}_{\mathrm{STP}} / \mathrm{L}\right)-\mathrm{VS}$ to a straight line, the methane yield coefficient coincides with the slope of the regression line. Table 4 shows the methane yield coefficient of all experiments. The methane yield obtained from mono-digestion of CM was $107 \mathrm{~mL}_{\mathrm{STP}} / \mathrm{g}$ VS was slightly lower than reported by Moller et al. (Moller et al., 2004) who obtained a methane yield of $148 \mathrm{~mL}_{\mathrm{STP}} / \mathrm{g} \mathrm{VS}$. Concerning the methane yield obtained by mono-digestion of $\mathrm{BW}$, the value obtained was $316 \mathrm{~mL}_{\mathrm{STP}} / \mathrm{g}$ VS. This value is in line with that obtained by the study of Gunaseelan, (Gunaseelan, 2007), who tested the mesophilic anaerobic digestion of three varieties of banana peel, the methane yield obtained was between $314 \mathrm{~mL} / \mathrm{g}$ VS and 321 $\mathrm{mL} / \mathrm{g}$ VS. In addition the rich composition in glucose (glucan) of banana waste $77.5 \%$ TS (Table 3) contribute positively to increase methane production. 


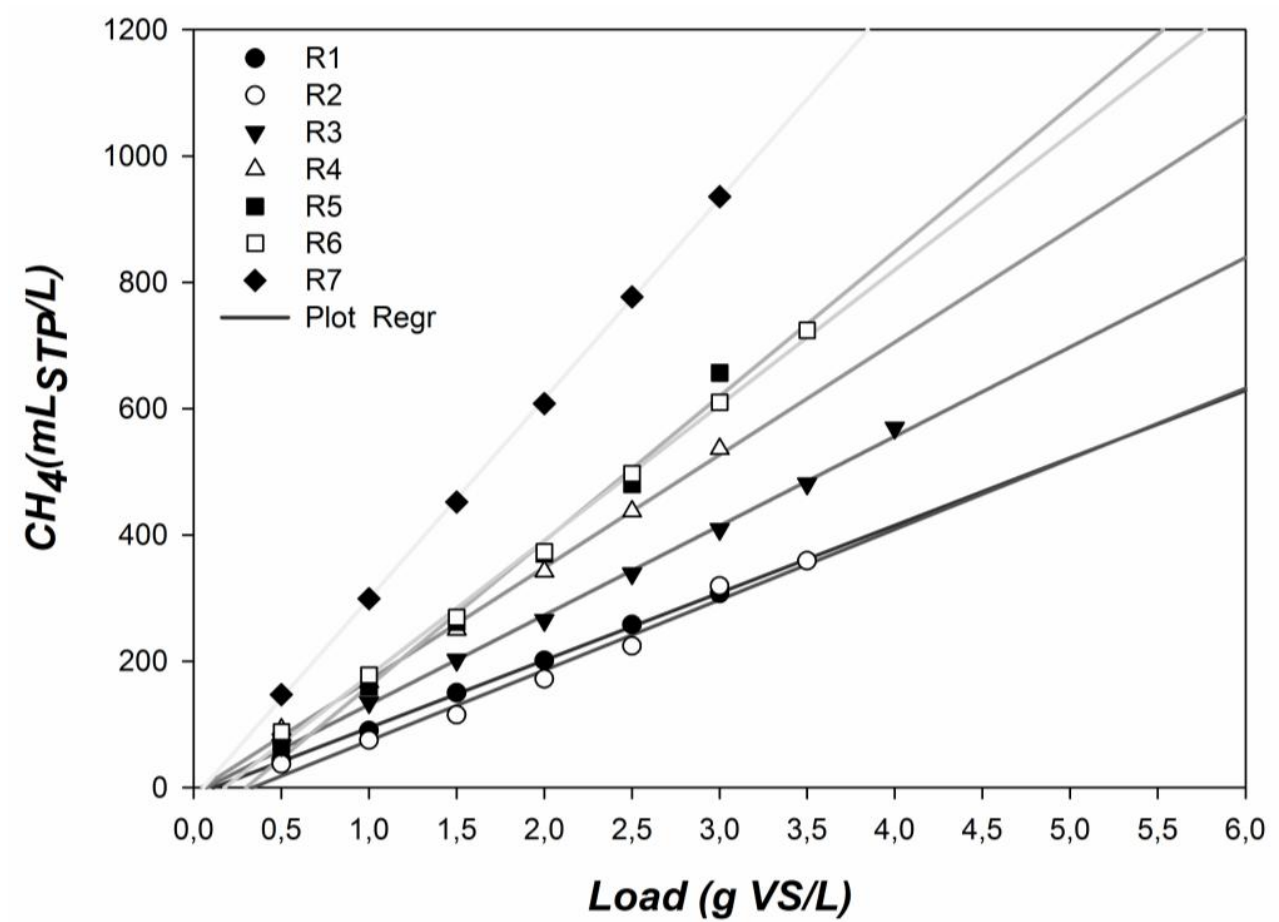

Figure 4. Variation of the experimental maximum methane volume produced with the VS added to obtain the methane yield coefficient of the process of different digesters.

For anaerobic co-digestion experiments, the results indicate that an increase in banana waste also increases the methane yield (Figure 5). An optimum was reached with a BW concentration of $60 \%$. There was no further improving when increasing the $\mathrm{BW}$ concentration to $80 \%$, the maximum methane yield of $229 \mathrm{~mL}_{\mathrm{STP}} \mathrm{CH} 4 / \mathrm{g}$ VS was obtained by digester R5 where the CM/BW ratio is 40/60. Thus, our study shows the added value of banana waste as co-substrate with cow manure, and the increasing the proportion of BW from $20 \%$ to $60 \%$ improve the methane yield from 112 to $229 \mathrm{~mL}_{\text {STP }}$ $\mathrm{CH} 4 / \mathrm{g} \mathrm{VS}$; the results obtained are in line with other findings e.g. Fang et al. (Fang and Angelidaki, 2011) who studied the thermophilc anaerobic digestion of by-products from sugar production with cow manure. They found a methane potential of $240 \mathrm{~mL} / \mathrm{g}$ VS in $\mathrm{CM} /$ Sugar beet by-products of 50:50 (wet basis). It should be noted that despite the high percentage of biodegradability which reached $92 \%$ in digester R6, we obtained a methane yield lower than that observed in digester R6 which have a biodegradability of 86\%. In fact, Triolo et al. (Triolo et al., 2011) reported that methane yield cannot be directly related to biodegradability, since methane yield reflects the destruction of organic materials, and the methane potential of each organic component in the volatile solids (VS) varies widely.

\section{Kinetics of methane production}

Kinetic studies of anaerobic digestion process are useful to predict the performance of digesters and design appropriate digesters and are also helpful in understanding inhibitory mechanisms of biodegradation (Rao and Singh, 2004). A first order kinetic model was used to characterize each set of experiments kinetically as was described by Borja et al. (1995). This kinetic model fit the experimental methane production volumes 
against the time for low substrate concentrations. The kinetic characterization allows comparing the proposed anaerobic co-digestion with other ones (Belhadj et al., 2014).

$$
G=G_{m} \times\left(1-e^{-K \times X \times t}\right)
$$

(Eq. 1) allows relating the accumulated volume of methane $(\mathrm{G}, \mathrm{mL})$ with time $(\mathrm{t})$ once the concentration of sludge $(\mathrm{X})$ and the kinetic constant $(\mathrm{K})$ are known. Moreover, the previous equation can be reordered in the form shown in (Eq.2), as microorganism concentration is considered to be constant (Serrano et al., 2014).

$$
G=G_{m} \times\left(1-e^{-K^{\prime} \times t}\right)
$$

The $\mathrm{K}^{\prime}$ and $\mathrm{G}_{\mathrm{m}}$ values for each load were calculated numerically from the experimental data obtained by nonlinear regression using Sigma-Plot (version 12.5).To evaluate the variations in experimental data, the theoretical values of maximum methane production $\left(\mathrm{G}_{\mathrm{m}}\right)$ for all experiments were calculated using (Eq. 2) and plotted against their corresponding experimental values. Figure 6 shows an example of the theoretical values of maximum methane production $\left(\mathrm{G}_{\mathrm{m}}\right)$ adjusted to their corresponding experimental values $\left(\mathrm{G}_{\mathrm{T}}\right)$ of digester $\mathrm{R} 5$.

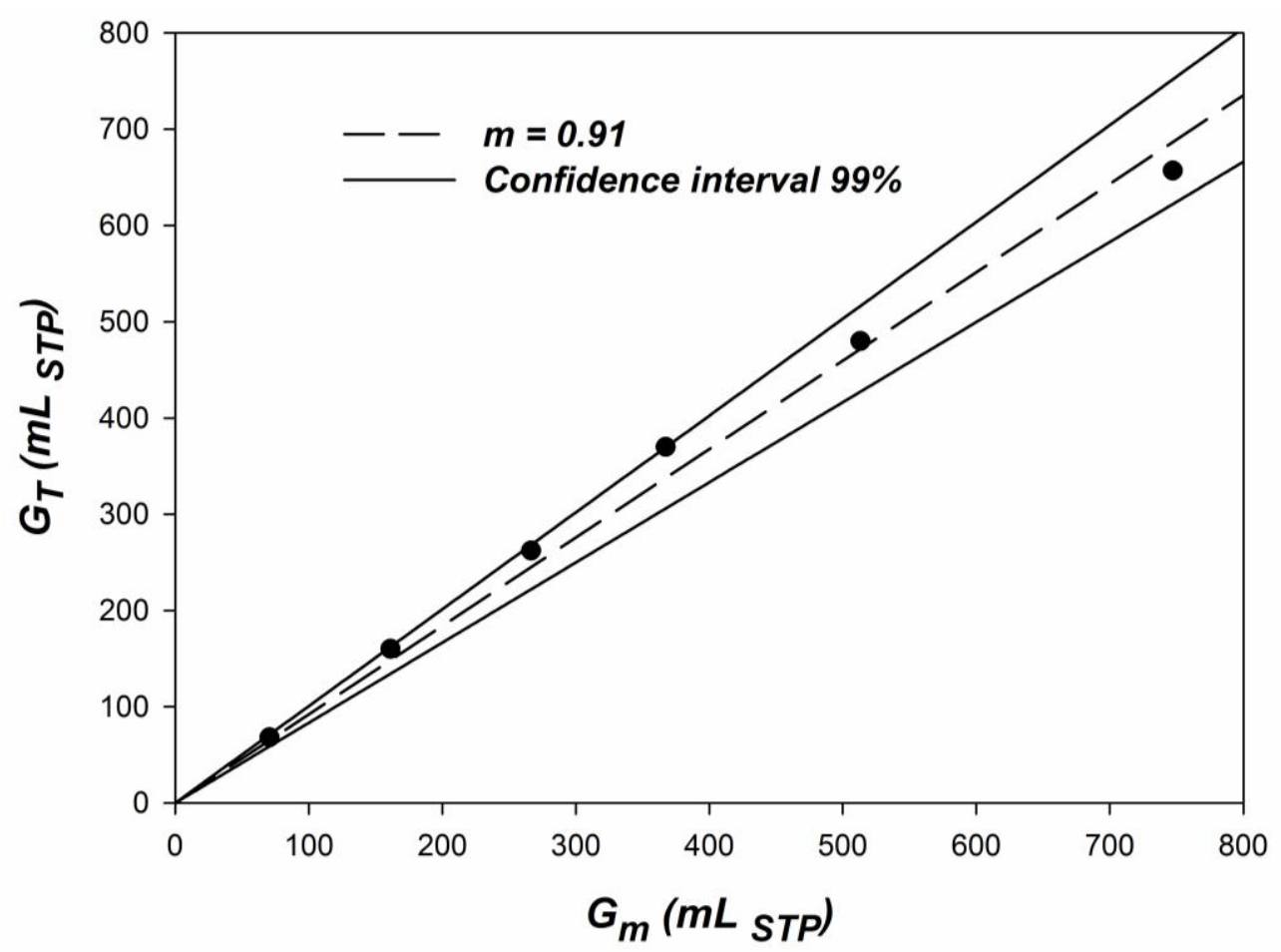

Figure 5. Comparison between the experimental maximum methane production values (GT) and the theoretical values $(\mathrm{Gm})$ of digester $R 5$ predicted by (Eq. 2). 
Moreover, the theoretical methane yield of all experiments was calculated by fitting pairs of values of the maximum theoretical volume of methane predicted in each load $\left(\mathrm{mL}_{\mathrm{STP}} / \mathrm{L}\right)-\mathrm{VS}$ to a straight line, the theoretical methane yield coefficient coincides with the slope of the regression line (Table 4). The predicted methane potential (Yt) increased with increased portion of BW except in the case of digester R6 in which the experimental as well as theoretical methane potential decreased when the BW was increased to 80. It should be noted that the theoretical methane yield (Yt) was higher than the experimental methane yield (Ye) in all co-digestion experiment, except in digester R6 and R7. The data of the experimental methane yield (Ye) was found to fit well (R2 values between 0.9823 and 0.9996). At the same time, digester R7 got the maximal theoretical methane yield of $315 \mathrm{~mL}$ STP $/ \mathrm{gVS}$.

Table 4. Difference between experimental and theoretical methane yield, and the correspond OLR of each digester.

\begin{tabular}{c|c|c|c|c|c|c|c}
\hline Digesters & $\mathbf{R 1}$ & $\mathbf{R 2}$ & $\mathbf{R 3}$ & $\mathbf{R 4}$ & $\mathbf{R 5}$ & $\mathbf{R 6}$ & $\mathbf{R} 7$ \\
\hline $\mathrm{Ye}_{\mathrm{CH} 4}\left(\mathrm{~mL}_{\mathrm{STP}} / \mathrm{gVS}\right)$ & 107 & 112 & 141 & 178 & 229 & 214 & 316 \\
\hline $\mathrm{r}^{2}$ & 0.9991 & 0.9823 & 0.9981 & 0.9975 & 0.9867 & 0.9967 & 0.9996 \\
\hline $\mathrm{Yt}_{\mathrm{CH} 4}\left(\mathrm{~mL}_{\mathrm{STP}} / \mathrm{gVS}\right)$ & 134 & 138 & 160 & 187 & 259 & 193 & 315 \\
\hline $\mathrm{OLR}\left(\mathrm{kg} \mathrm{VS} /\left(\mathrm{m}^{3} . \mathrm{d}\right)\right)$ & $0.17-1.1$ & $0.48-$ & $0.53-$ & $1.17-$ & $1.49-$ & $0.66-$ & $0.58-2.8$ \\
\hline
\end{tabular}

\section{Organic loading rate}

Organic Loading Rate (OLR) is defined as the rate of organic matter to be introduced to a digester. OLR is an important control parameter in anaerobic digestion; overloading could lead system to fail, due to the accumulation of inhibiting substances. Therefore the organic loading rate (OLR) relates the amount of waste added to the reactors with the reactor volume and time. The operational conditions used in this study allow the added substrate to be biomethanised as much as possible.

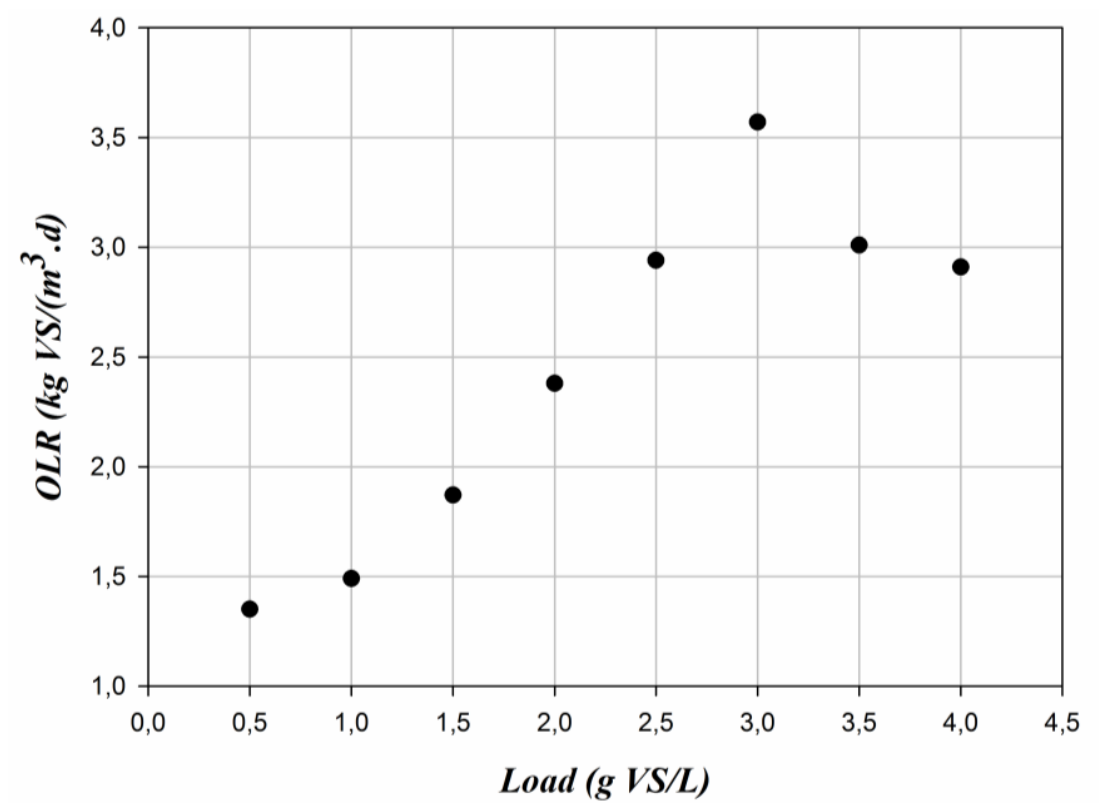

Figure 6. Variation of organic loading rate against the load added of digester R5. 
Figure 7 shows the variation of the OLR $\left(\mathrm{kg} \mathrm{VS} /\left(\mathrm{m}^{3} . \mathrm{d}\right)\right)$ with the added load to the digester R5. OLR was calculated considering the substrate concentration added to the reactors $\left(\mathrm{kg} \mathrm{VS} / \mathrm{m}^{3}\right.$ ) and the time (day) required to reach $95 \%$ of the total methane production for each load (Serrano et al., 2013). Digester R5 gave a maximum amount of organic matter which could be treated; its OLR values increased from 1.49 to $3.57 \mathrm{~kg}$ $\mathrm{VS} /\left(\mathrm{m}^{3} \cdot \mathrm{d}\right)$. Although the methanogenic potential obtained in the case of mono-digestion of banana waste is high to that obtained from the co-digestion, but it should be noted according to the Table 4 that the OLR which can be treated in the case of the codigestion experiments (digester R5) is much more important.

\section{Conclusion}

A mesophilic anaerobic co-digestion of Cow Manure (CM) and Banana Waste (BW), was evaluated using a 1-liter Labe-scale CSTR anaerobic digesters. Seven CM/BW mixtures ratios were tested. Mono-digestion of cow manure and banana waste gave methane yield of 107 and $316 \mathrm{~mL}_{\mathrm{STP}} / \mathrm{g}$ VS respectively. For co-digestion experiments, a maximum methane yield of $229 \mathrm{~mL}$ STP $/ \mathrm{g}$ VS was obtained when mixing $40 \% \mathrm{CM}$ with $60 \% \mathrm{BW}$ at a final biodegradability of $86 \%$. The addition of banana waste as cosubstrate in the mixture improved methane yield as well as OLR which was reached a value of $3.57 \mathrm{~kg} \mathrm{VS} /\left(\mathrm{m}^{3} . \mathrm{d}\right)$.

The results show a high biogas potential and high suitability of banana waste as a feedstock for economically viable waste-treatment technology like anaerobic digestion for the purpose of energy generation in the form of methane. Hence, anaerobic codigestion of cow manure mixed with banana waste could generate significant amounts of energy supply in form of biogas that could be used to cover essential needs.

Acknowledgements. The authors are very grateful to the European Commission for financing the BIOWASTE4SP - project, Grant agreement No. 312111 (www.biowaste4sp.eu).

\section{REFERENCES}

[1] American Public Health Association (1989): Standard methods for examination of water and wastewater. 17th ed. Washington (DC).

[2] Angelidaki I., Ellegaard, L. (2003): Codigestion of manure and organic wastes in centralized biogas plants. - Applied Biochemistry and Biotechnology 109: 95-105.

[3] Angelidaki, I., Sanders, W. (2004): Assessment of the anaerobic biodegradability of macropollutants. - Reviews in Environmental Science and Bio/Technology 3(2): 117129.

[4] Ann-Wilkie, C. (2005): Anaerobic digestion of dairy manure: design and process consideration, Natural Resource, Agriculture, and Engineering Service - Cornell University, Ithaca, NY, , pp. 301-312.

[5] Astals, S., Nolla-Ardèvol, V., Mata-Alvarez, J. (2013): Thermophilic co-digestion of pig manure and crude glycerol: process performance and digestate stability. - Journal of Biotechnology 166: 97-104.

[6] Banks, C.J., Salter, A.M., Heaven, S., Riley, K. (2011): Energetic and environmental benefits of co-digestion of food waste and cattle slurry: a preliminary assessment. Resources, Conservation and Recycling 56: 71-79.

[7] Bardiya, N., Somayaji, D., Khanna, S. (1996): Biomethanation of banana peel and pineapple waste. - Bioresource Technology 58: 73-76. 
[8] Belhadj, S., Joute, Y., El Bari, H., Serrano, A., Gil, A., Siles, A.J., Chica, A.F., Martín, M.A. (2014): Evaluation of the anaerobic co-digestion of sewage sludge and tomato waste at mesophilic temperature. - Applied Biochemistry and Biotechnology 172: 38623874.

[9] Borja, R., Martín, A., Banks, C.J., Alonso, V., Chica, A. (1995): A kinetic study of anaerobic digestion of olive mill wastewater at mesophilic and thermophilic temperatures. - Environmental Pollution 88: 13-18.

[10] El-Mashad, H.M., Zhang, R. (2010): Biogas production from co-digestion of dairy manure and food waste. - Bioresource Technology 101: 4021-4028.

[11] Fang, C., Boe, K., Angelidaki, I. (2011): Anaerobic co-digestion of by-products from sugar production with cow manure. - Water Research 45: 3473-3480.

[12] Frigon, J.C., Roy, C., Guiot, S.R. (2012): Anaerobic co-digestion of dairy manure with mulched switchgrass for improvement of the methane yield. - Bioprocess and Biosystems Engineering 35: 341-349.

[13] Gunaseelan, V.N. (2007): Regression models of ultimate methane yields of fruits and vegetable solid wastes, sorghum and napiergrass on chemical composition. - Bioresource Technology 98: 1270-1277.

[14] Gustavsson, M., Bjerre, A.B., Bayitse, R., Belmakki, M., Gidamis, A.B., Hou, X., El Houssine, B., Owis, A.S., Sila, D.N., Rashamuse, K., Sundqvist, J.O., El-Tahlawy, Y., Tawona, N. (2014 ): Catalogue of Biowastes \& Bioresidues in Africa. - Biowaste4SP project deliverable, Danish Technological Institute and IVL Swedish Environmental Research Institute, Taastrup, Denmark.

[15] Khan, M.T., Maurer, C., Argyropoulos, D., Brule, M., Mueller, J. Anaerobic Digestion of Banana Waste, a Potential Source of Energy in Uganda. Conference Paper. TropentagHamburg, p. 451, 6-8 October 2009.

[16] Li, Y., Park, S.Y., Zhu, J. (2011): Solid state anaerobic digestion for methane production from organic waste. - Renewable \& Sustainable Energy Reviews 15: 821-826.

[17] Marañón, E., Castrillón, L., Quiroga, G., Fernández-Nava, Y., Gómez, L., García, M.M. (2012): Co-digestion of cattle manure with food waste and sludge to increase biogas production. - Waste Management 32: 1821-1825.

[18] Mata-Alvarez, J., Dosta, J., Macé, S., Astals, S. (2011): Codigestion of solid wastes: a review of its uses and perspectives including modelling. - Critical Reviews in Biotechnology 31: 99-111.

[19] Mata-Alvarez, J., Dosta, J., Romero-Güiza, M.S., Fonoll, X., Peces, M., Astals, S. (2014): A critical review on anaerobic co-digestion achievements between 2010 and 2013. Renewable \& Sustainable Energy Reviews 36: 412-427.

[20] Moller, H.B. Sommer, S.G., Ahring, B.K. (2004): Methane productivity of manure, straw and solid fractions of manure. - Biomass and Bioenergy 264: 85-495.

[21] Nizami, A.S., Korres, N.E., Murphy, J.D. (2009): Review of the integrated process for the production of grass biomethane. - Environmental Science \& Technology 43(22): 84968508.

[22] Rao, M.S., Singh, S.P. ( 2004): Bioenergy conversion studies of organic fraction of MSW: kinetic studies and gas yield-organic loading relationships for process optimisation. - Bioresource Technology 95: 173-185.

[23] Raposo, F., De la Rubia, M.A., Fernández-Cegrí, V., Borja, R. (2011): Anaerobic digestion of solid organic substrates in batch mode: An overview relating to methane yields and experimental procedures. - Renewable \& Sustainable Energy Reviews 16: 861-877.

[24] Serrano, A., Siles, A.J., Chica, A.F., Martín, M.A. (2013): Agri-food waste valorization through anaerobic co-digestion: fish and strawberry residues. - Journal of Cleaner Production 54: 125-132. 
[25] Serrano, A., Siles, A.J., Chica, A.F., Martín, M.A., Karouach, F., Mesfioui, A., El Bari, H. (2014): Mesophilic anaerobic co-digestion of sewage sludge and orange peel waste. Environmental Technology 35(7): 898-906.

[26] Triolo, J.M., Sommer, S.G., Møller, H.B., Weisbjerg, M.R., Jiang, X.Y. (2011): A new algorithm to characterize biodegradability of biomass during anaerobic digestion: influence of lignin concentration on methane production potential. - Bioresource Technology 102: 9395-9402. 